\title{
The concept of equality in Spinoza's Theological-Political Treatise
}

Beth Lord, University of Aberdeen, s.b.lord@abdn.ac.uk

Philosophy Department

School of Divinity, History and Philosophy

The Old Brewery

University of Aberdeen

Aberdeen

AB24 3UB

UK

\section{Abstract:}

Freedom and equality are important aspects of our self-conception as democratic citizens. Spinoza recognizes that these ideals also shape our thoughts about ourselves as human beings, and shows in his Theological-Political Treatise how the democratic state allows us to realize that self-conception. While Spinoza scholars continue to puzzle over what freedom means in the Theological-Political Treatise and how democratic political freedom relates to the ethical freedom of the Ethics, similar attention has not been given to equality. Although many believe that Spinoza endorses equality in some way, little has been said about the kinds of equality he discusses and how and why he endorses them. Here I argue that because Spinoza takes human beings to have unequal power, he takes them to be of unequal moral status (in the sense of ethical goodness), and his theory of democracy is not based on a concept of moral equality. Democracy, for Spinoza, gives rise to political equality, which frees us to become more powerful and generates the useful image of equal respect, but does not necessarily cause people to increase their power or moral status. The kind of equality that, for Spinoza, encourages human beings to become ethically free is economic equality, as I show with reference to the example of the Hebrew state in the Theological-Political Treatise and Spinoza's remarks on economic exchange and the passions in the Ethics. 


\section{Introduction}

Freedom and equality are important aspects of our self-conception as democratic citizens. ${ }^{1}$ Spinoza recognizes that these ideals also shape our thoughts about ourselves as human beings, and shows in his Theological-Political Treatise how the democratic state allows us to realize that self-conception. Both there and in the Ethics, however, Spinoza shows that the majority of human beings most of the time conceive themselves erroneously, according to imaginaries both personal and collective. ${ }^{2}$ While genuine freedom can be achieved by the wisest, the unfree majority live under the illusion of their own freedom, understood as free will or free choice: an illusion which the state may promulgate in order to maintain peace. Spinoza scholars continue to puzzle over what freedom means in the Theological-Political Treatise and where democratic political freedom sits on the spectrum from illusory free will to the true ethical freedom of the Ethics. ${ }^{3}$

Similar puzzles have not generally arisen over equality, perhaps because equality is not named as a human good in the Ethics. Many commentators think that Spinoza is against inequality in at least some forms, and some assume that his concept of democracy includes an endorsement of equality. ${ }^{4}$ The Theological-Political Treatise appears to support this assumption: a democracy is a state in which "all remain equal, as they had been ... in the state of nature", and is to be preferred to monarchy in part because no one can tolerate being ruled by their equals. ${ }^{5}$ Within a democratic state, the law is obliged to treat people as equals and defend their right equally, and the Hebrew state prospered partly because of its egalitarian practices. $^{6}$ Even these few examples suggest that Spinoza's sense of equality is not uniform, and that he draws on different kinds of equality including equal political right, equality 
under the law, and economic equality. I want to stress that Spinoza's appeals to equality are actually rather ambiguous, and - like his appeals to freedom - are complexly entangled with the philosophical positions of the Ethics. I will examine Spinoza's remarks about the state of nature and the civil state, and argue that while the political equality gained in a democracy frees us to become more powerful, it does not necessarily cause people to increase their power or virtue. I then turn to Spinoza's example of the Hebrew state in the Theological-Political Treatise, and his remarks on economic exchange, charity, and the comparative passions in the Ethics, to argue that it is economic equality that, for Spinoza, encourages human beings to become virtuous and ethically free.

\section{The inequality of reason}

A problem concerning inequality is at the core of Spinoza's Theological-Political Treatise: 'Everyone without exception can obey, not merely the very few - very few, that is, in comparison with the whole human race - who acquire the habit of virtue by the guidance of reason alone'.

The nature of the problem is illuminated by Spinoza's Ethics. Spinoza establishes there that people will always differ in rationality, virtue, and freedom. These three are bound together because they all reflect the extent to which we bring about our own thoughts and actions. To reason is to think according to a sequence of true ideas that is essential to and follows necessarily in the human mind, which we discover and recover through experience. ${ }^{8}$ (By contrast, to imagine is to think according to contingent chains of confused ideas established by empirical associations 
between external things.) Virtue "is the very essence, or nature, of man, insofar as he has the power of bringing about certain things, which can be understood through the laws of his nature alone". ${ }^{9}$ Virtue increases the more we strive and are able to preserve our being and to act according to what we rationally know our essence to be. (By contrast, lack of virtue is neglecting to preserve our being or to strive for it, due to being overpowered by external things, and is correlated with imagination and reactive affects.) As reason increases, we understand our own essence better and what is good for it, and we strive to achieve what is good for us, increasing our virtue. As we think and act more autonomously - according to our nature rather than according to the sway of fortune - we become more free: "that thing is called free which exists from the necessity of its nature alone, and is determined to act by itself alone". ${ }^{10}$ (By contrast, to be "enslaved" is to be overwhelmingly determined by one's circumstances and one's reactive affects.) Spinoza is clear that the route to greater reason, virtue, and freedom is not straightforward. Everybody is subject to external things and the entwined images and feelings they cause. ${ }^{11}$ Our material circumstances can encourage or constrain our success, meaning that our power to determine our own thoughts and actions fluctuates constantly as it is more or less affected by external things.

Due to differing circumstances and fluctuating fortunes, people are not equal in the extent to which they develop reason, virtue, and freedom. Only very few will become highly virtuous and rational, and even they are subject to the diminishment of those goods in bad circumstances. By contrast, everyone has an equal capacity to act in accordance with virtue, regardless of their understanding of the reasons for it, by following models and obeying laws. One of the questions guiding the TheologicalPolitical Treatise is how society should be organized given that people can be equally obedient but not equally rational. How can all people be led to act uniformly in the 
interests of peace and stability, given that they do not (and will never) think or feel in harmony with one another? ${ }^{12}$

Spinoza's response is that behaviour should be tightly legislated, but that thought and speech cannot and should not be. ${ }^{13}$ Obedience is best inculcated through the institution of a universal faith. In the Ethics, Spinoza argues that God is equivalent to nature and is to be rationally understood rather than worshipped. But only the wisest will come to understand God in that way. Human societies are made up primarily of the less rational - the more imaginative and reactive - and all will benefit from a system that guides their behaviour to approximate true virtue through narratives and feelings of devotion. Spinoza's universal religion accommodates a range of historically and culturally variable beliefs and practices; what is crucial is its core tenet that love of God demands obedience to the law to love one's neighbours. ${ }^{14}$ This "divine law" of the old and new testaments is best for encouraging virtuous behaviour because it is also a law of human nature: it is truly virtuous to act for the advantage of other human beings. ${ }^{15}$ Whether we grasp this law through rationally understanding our own nature or through imagining it to be a divine commandment is less important than that we obey it through our actions.

We love our neighbours by showing them justice and charity, a practice that encourages peaceful societies even if rationality in the population is low. ${ }^{16}$ To be a good person involves rationality, virtue, and freedom; to be a good citizen involves only obedience to the law to love one's neighbours. In a democracy, Spinoza defines justice as fairness or equity, assigning to each person what belongs to him according to civil law, and "to treat all as equal, ... not begrudging the rich or despising the poor". ${ }^{17}$ At a minimum, if the law to love one's neighbours is to be universally followed, then each person deserves to receive the love of his or her neighbours. 
While the precise content of that law must be determined by each society, its form indicates that each person merits a fair distribution of neighbourly love, irrespective of that person's wealth or standing in society. This suggests that Spinoza's democracy involves the principle that all people are equally valued and respected. We might call this a principle of equal dignity, or moral equality: it is a principle on which we take modern democracy to be founded, and it may appear that it is at the heart of Spinoza's idea of democracy too. ${ }^{18}$ That principle, however, seems to conflict with Spinoza's conviction that some people, namely the more rational ones, are better and more valued than others. How does Spinoza understand equality to function in a democracy?

\section{Democratic equality}

Moral equality is not part of our essence and does not follow necessarily from our nature; unlike earlier natural law theorists and later Enlightenment philosophers, Spinoza does not think that our capacity for reason makes us equal in a moral sense. ${ }^{19}$ The Ethics suggests that human beings have a formal sameness which does not imply moral equality. I take this formal sameness to be grounded in a shared formal essence - the eternal blueprint of human being that follows from the essence of God, or nature - which gives us a common set of basic physical and mental capacities. Our common physical capacities mean that all human individuals have the same basic body-plan, while our common mental capacities mean that every human being is able to reflect its body in thinking. The mind, for Spinoza, is nothing more (and nothing less) than the idea of the body: it is not a rational being that could be said to have any special value or moral status. Furthermore, formal essence cannot be isolated from its 
actualizations in existing human beings and their circumstances. People are, and always will be, unequal in their rationality, virtue, and freedom - the only qualities in which our moral status could be said to reside, for Spinoza. So while a basic human sameness distinguishes us from other kinds of individuals, it does not make us equally worthy of justice or respect; nor does our humanness give us any special value in nature. If moral equality is a feature of Spinoza's system, it follows in the democratic state from our following the divine law, and is not the foundation for our doing so.

People are equally able to be good citizens by following the divine law, and are consequently treated equally as citizens under civil law. Yet Spinoza also suggests that we are "equals" in the state of nature, prior to the development of democracy, law, or citizenship. ${ }^{20}$ If we are not by nature morally equal, then what is the basis of this natural equality? In the state of nature, Spinoza says, "everyone exists by the highest right of Nature" and "each individual thing has the sovereign right to do everything that it can do". ${ }^{21}$ This follows from the fact that in the state of nature, the sovereign power is nature itself. According to Spinoza's metaphysics, nature's power is equivalent to God's power and to "the power of all individual things together". To the extent that an individual has power within nature, it has the sovereign right to do what its power determines it to do: "the right of each thing extends so far as its determined power extends". ${ }^{22}$ By "right" Spinoza does not mean an entitlement, but the essential power of a thing to be what it is and strive for what is good for it. ${ }^{23}$ Thus God's (or nature's) right is the power "by which he and all things are and act", and an individual's right is the power (conatus) by which it strives to persevere in its being. ${ }^{24}$ The power, and thus the sovereign right, of individuals is not equal in nature: big fish eat little fish, and "we recognize no difference between human beings and other individual things of nature" in this respect. ${ }^{25}$ People in different circumstances 
encounter different helps and hindrances to sustaining and enhancing their being. Accordingly, people's power to survive and seek their advantage differs and varies over time. The rational person who understands her nature has the power and the right to act according to the laws of her nature, while someone who lacks this understanding has the power and the right to live according to the demands of his appetites.

It is unlikely that anyone will achieve much rational understanding in the state of nature. Nobody is born understanding the laws of their nature, and the state of nature is not conducive to gaining it. In conditions where "anyone ... is permitted by the sovereign right of nature to desire anything that he believes to be useful to himself $[\ldots$ and] is permitted to take it for himself by any means", people's thoughts and actions will be overwhelmingly determined by the need to survive and by passions of fear, hatred, and anger. ${ }^{26}$ Spinoza demonstrates in the Ethics that such a situation is detrimental to the development of reason and virtue, partly because people who are determined by their passions have little in common with each other, and thus few opportunities to understand human nature or to unite to increase their power. ${ }^{27}$ Any reason and virtue a person manages to develop will be precarious, as that person continues to be subject to external threats and the unchecked desires and passions of others.

A kind of equality does, nevertheless, characterize human life in the state of nature. The state of nature is not organized around rational human interests but is determined by the powers of all individual things together. Accordingly, human beings are equally subject to the 'numberless things that concern the eternal order of the whole of nature, of which human beings are but a small part' ${ }^{28}$ In the state of nature one lives according to the sway of fortune and external causes, and is largely 
unable to determine oneself. So freedom is fairly equal, since everyone is unfree. Furthermore, this regime treats human beings with no special value and gives them no special rights. From the perspective of God or nature, human interests are of no greater worth than those of lions or viruses: they take precedence only to the extent that humans exercise greater power. The human species is equal to other species, and a human individual is equal to another individual, in that its right is strictly concomitant with its power. In this sense, humans are equal in their intrinsic valuelessness. Finally, since everyone in the state of nature "decides what is good and what is evil from his own temperament", ${ }^{29}$ everyone who manages to act for their own advantage is equally "good". A more rational person's interests and actions (to acquire what she needs through mutual aid) are of no greater value, and are no better, than those of the ignorant person (to acquire what he needs by deception or murder).

Since reason, virtue, and freedom are universally low in the state of nature, their more equal distribution does nothing to enhance human flourishing. Evidently, being equal to others in these respects is not, in itself, good for us. Moreover, these equalities indicate a lack of proportion between a person's power and her goodness. For Spinoza, a person's goodness consists in the extent to which she has been able to "perfect" herself to think rationally, act virtuously, and live freely according to her own nature. This gives a person a moral status which increases as her power, or conatus, increases: "by virtue and power I understand the same thing". ${ }^{30}$ One way in which the state of nature is bad for human nature is that this equation is disrupted. Where virtue is universally low, and where goodness is defined by each individual in terms of the satisfaction of his needs, everyone's moral status is roughly equal. A more powerful person will gain material advantages such that he will be stronger and 
longer-lived: he may be a better person on his own terms, but he will not be a better person in the human ethical sense set out in the Ethics.

It is only in a human state, organized according to human interests, that this disproportion is addressed. Under conditions that protect us from danger, regulate human interaction, and direct our behaviour to the general human advantage, we have opportunities to work together to understand human nature and to become more powerful in ways that lead us to being ethically better people. The purpose of the state is "to free everyone from fear ... [and] allow their minds and bodies to develop in their own ways in security and enjoy the free use of reason". ${ }^{31}$ The state gives us the "freedom" - in the sense of protection from the damaging effects of other powers - to become more free in the ethical sense, and thus to become ethically better and increase our moral status. This will not happen universally: within the political space of freedom, many are still enslaved in the ethical sense. Due to people's different conative powers and circumstances, some will become better and others will not. This leads to differences in people's value for society. Those who are more powerful here are also more rational and virtuous, and are more useful to one another; such people are more highly valued, at least by those who rationally understand what is most valuable for human beings. ${ }^{32}$ In a democracy, inequalities in power rightly give rise to proportionate inequalities in moral status.

In a democracy, people escape enslavement to their circumstances and become subjects of a collective self-governing power that they form themselves. In contrast to Hobbes, individuals transfer their natural right to society without thereby losing it, because they share their power with that of others in a much bigger power. "In a democracy no one transfers their natural right to another in such a way that they are not thereafter consulted but rather to the majority of the whole society of which they 
are a part. In this way all remain equal as they had been previously, in the state of nature". ${ }^{33}$ In what sense are democratic citizens equals? First, they are as equal as those in the state of nature in the sense that each person is equally subject to a much more powerful whole. Second, they are equal in the new sense of having equal civil right: each one trades in his natural right for an equal stake in the collective whole. This equal stake is not based on the intrinsic moral equality of persons, but on a revocable agreement to collectivize and share natural right. Democracy is this collectivized sovereign right. Each person is an equal share of the sovereign right, while retaining his natural right (conative power) through which he seeks his advantage within the constraints of civil law.

The transfer of right thus introduces a distinction between power as right and power as conatus which did not exist in the state of nature. ${ }^{34}$ It is a condition of a democracy that the former is equalized so that the latter is "freed" to develop itself as best it can. Our moral status can grow and flourish in a democracy; but it can also diminish and languish if we lack the resources and opportunities to develop it. Potentially, a large gap may open between those who are better enabled to flourish and those who are less so. Having freed people to increase their power, pursue ethical freedom and improve their moral status, the state is not obliged to redress inequalities in the extent to which people actually attain these goods. A democracy seeks to exercise its own conative power to the advantage of the whole; that is, it aims to persevere in its existence and grow stronger. It acts for security and stability, not for greater equality. The state may decide to distribute or redistribute goods to minimize disparities in power and moral status, but if it does so, its purpose is not to equalize those goods but to increase the power of the whole. 
The equalization of right does not ensure moral equality, but it does allow for the performance of equal respect. Justice is "to have no respect of persons, but to treat all as equal, and equally to defend the right of each individual". ${ }^{35}$ Equal right ensures the political and legal equality of democratic subjects. ${ }^{36}$ Because it gives equal access to justice and charity, everyone is perceived to be equally entitled to be valued and respected. But this perception is illusory, since people are truly valued on the basis of their moral status which is not equal, and which the democratic state has no obligation to make equal. One state might find it most useful to improve its whole population, and redistribute educational resources from the most powerful to the least in order to achieve higher levels of reason across the board. Another might find that peace and stability are best achieved by maintaining large disparities of moral status, valuing its more virtuous citizens more highly and explicitly giving their interests greater weight (as in Plato's Republic). Some states might find it useful to perpetuate the illusion of moral equality to satisfy people's self-conceptions and desire for recognition, and prevent envy and resentment. ${ }^{37}$ Although democracy allows us to treat everyone as if they were equally respected, it does not take the real moral equality of persons to be a grounding assumption or an aim. This is one of many ways in which Spinoza's concept of democracy is distant from our own.

Rational people recognize that they are superior to, and more valuable for humanity than, the ignorant. But the ignorant do not necessarily recognize the superiority of the rational: taking their own self-interest to be all-important, they think of themselves as morally equal to everyone else. It may therefore be difficult to persuade them to follow laws determined by others: "there is nothing that people find less tolerable than to be ruled by their equals and serve them". ${ }^{38}$ For this reason, the civil authority must be seen to be superior to its subjects. The state should be a 
democracy ruled by a collective whole which is, by definition, superior in power and value to each of its parts: "all are subject to themselves and nobody must serve their

equal". ${ }^{39}$ If it is not a democracy, a state should be ruled by one or several people who have "something above ordinary human nature", or who can convince others that they do. Moses, in Spinoza's example, was truly more rational and virtuous than his fellow Israelites, while the Romans derived their superiority from their purported divine lineage. ${ }^{40}$

To summarize, Spinoza does not take equality to be an intrinsic feature of human beings or to be good in itself. Equality is good only to the extent that it promotes the flourishing of individuals and the strength and stability of the state. Democracy introduces legal and political equality which "free" us to unequally pursue greater rationality, virtue, and ethical freedom. The equal moral status of citizens may be imagined by the populace but is neither assumed nor desired by the wise, who aim to increase the moral status of as many individuals as possible. This leads to a new question: does Spinoza think that equality has a role to play in the rational aim to make more people better people? What kinds of equality promote the flourishing of individuals and communities, on Spinoza's view?

\section{Equality in the Hebrew state}

Spinoza discusses equality extensively in chapter 17 of the Theological-Political Treatise, where he moves from the theoretical discussion of democracy to the practical example of the Hebrew state under Moses. Spinoza's example is not accidental. The late-sixteenth and early-seventeenth centuries saw a "Hebrew revival" in Protestant republicanism, theorists of which upheld the Hebrew state rather than the 
Roman republic as exemplary. ${ }^{41}$ In the wake of the Reformation, "readers began to see in the five books of Moses not just political wisdom, but a political constitution $[; \ldots]$ a set of political laws that God himself had given to the Israelites as their civil sovereign". ${ }^{42}$ Political writers drew on rabbinical interpretations of the "Hebrew republic" and presented it as the divinely ordained model state. Things went even further in the seventeenth-century Dutch republic: representing their independence from Spain in terms of the struggle of the Batavians against Rome, the Dutch adopted the Hebrew state as their own foundation myth. From political tracts to poetry, plays, and the decoration of town halls, "the United Provinces figured as the New Israel, and its constitution was represented as a revival of the divine law given to Moses". ${ }^{43}$ Petrus Cunaeus' De republica Hebraeorum of 1617, the first such text to draw on Maimonides' Mishneh Torah, was particularly influential in establishing the Hebrew state as a constitutional model for the Dutch. While for Cunaeus Hebrew history shows that monarchy is contrary to God's plan, other writers - including Grotius, Calvin, and Hobbes - interpreted it differently to support a range of political views. ${ }^{44}$ Spinoza wrote for a Dutch republican audience thoroughly familiar with the political uses of the Hebrew state. He is sceptical about its potential to serve as a direct model for the Dutch Republic: "no one can now imitate [the Hebrew state], and it would not be wise to try to do so". Nevertheless, it has "numerous features that are ... well worth noticing, and which it would perhaps be very wise to imitate". ${ }^{45}$ Two of these features, also stressed by Cunaeus, are the equal sovereign right of the Israelites, and their economic equality resulting from the "agrarian law". One of Cunaeus' particular contributions to the literature was his explicit analogy between the land laws described in the Bible and the Roman agrarian laws designed to periodically redistribute public land. ${ }^{46}$ Republicans who favoured the Roman model opposed the 
redistribution of property and wealth; Cunaeus countered that by establishing an "agrarian law" among the Israelites, God had mandated such redistribution. Cunaeus used the Hebrew state to argue not only that all legitimate constitutions are republican, but that all legitimate republics should adopt principles of equitable redistribution. $^{47}$

Spinoza describes the Israelites emerging from enslavement in Egypt and finding themselves in a state of nature, with their natural right fully restored to them. On Moses' advice, they agreed to transfer their right to God and promised to obey God's law alone. ${ }^{48}$ The Israelites made God their sovereign and sole lawmaker, thus creating a state in which civil law and religion were one and the same. Although their state was apparently a theocracy, this was "more opinion than reality", because it was based on an imaginary conception of God. ${ }^{49} \mathrm{God}$, truly understood, is not a legislator or a party to contracts; that characterization was a useful fiction. In imagining God to be their sovereign, the Israelites had unknowingly created a democracy:

The Hebrews did not transfer their right to another person but rather all gave up their right, equally, as in a democracy, crying with one voice: "We will do whatever God shall say" (making no mention of an intermediary). It follows that they all remained perfectly equal as a result of this agreement. The right to consult God, receive laws, and interpret them remained equal for all, and all equally without exception retained the whole administration of the state. This is why, on the first occasion, they all equally approached God to hear what he wished to decree. ${ }^{50}$

"God the sovereign" was a symbolic representation of the pooled power of the Hebrew people in which the people believed, and "God's laws" were human civil and religious laws imaginatively attributed to divine revelation. In making themselves 
equals under God's law, the Israelites made themselves equal lawmakers, since "to consult God, receive laws, and interpret them" is to conceive laws imaginatively and to imagine God to have communicated them. ${ }^{51}$ As long as the Israelites continued to imagine that God was their legislator, they in fact maintained their own sovereign right.

The Israelites had the collective power to imagine their own constitution and laws and to perpetuate the fiction of theocratic rule to maintain obedience. But the disadvantage of thinking imaginatively is its close connection to the passions. The Israelites evidently imagined and felt passions "with one voice": upon all equally approaching God to hear the law, they were terrified to the point of death. Perceiving Moses' superior wisdom, they made him the sole consultant to God. ${ }^{52}$ In this second transfer of right, Moses assumed the right to interpret and enforce the law, not as a king but as a sovereign representative of God (i.e. of the people's pooled power). Now the Israelites "lost absolutely every right" to make law and choose their form of government, and were equal only in the sense of being "equally subject" to the sovereign. ${ }^{53}$ But the sovereign was really their own pooled power which had been loaned to Moses, and they were really subject to themselves.

The repetition of the word "equal" in these passages indicates its importance in Spinoza's description of the Israelites' political transitions. In a democracy everyone has equal civil right, but a society in which everyone equally makes the law is not practicable when people are ruled by their passions. ${ }^{54}$ In this situation, equality will not lead to a flourishing society; it is better to concentrate legislative authority in one superior individual who borrows and represents the equal right of the people. To transform a fearful and ignorant mass into a stable and peaceful community, Moses had to inculcate obedience in every aspect of public and domestic life, from the order 
of religious ceremonies to the way they cut their hair. ${ }^{55}$ These strict behavioural controls made it possible for the Israelites to build a flourishing society and provide the conditions in which a person could "live under the guidance of reason with his whole mind". In making themselves subject to the command of the sovereign, they freed themselves to pursue their own ethical freedom: "a subject is one who does by command of the sovereign what is useful for the community and consequently also for himself". ${ }^{56}$

Moses' position as sovereign representative was not inherited. He bequeathed to the Israelites a theocracy in which legislative and administrative responsibilities were divided so that no one person held sovereign right. This led to a federation of equal, autonomous territories united under one God. ${ }^{57}$ A key element of the state's prosperity was its egalitarian distribution of goods. The temple was built at collective expense and "belong[ed] to all". The territory of the Canaanites was divided equally among the twelve tribes who invaded it. The citizens "held an equal portion of the lands and fields with the leader". ${ }^{58}$ Most important was the law that required land to be returned to those who had been compelled to sell it.

Nowhere else did citizens hold their possessions with a stronger right than this state's subjects. They held an equal portion of the lands and fields with the leader, and each one was the perpetual owner of his share. If anyone was compelled by poverty to sell his estate or field, he had to be restored to it again when the Jubilee came around, and there were other customs of this kind to ensure that no one could be dispossessed of his allotted property. Nowhere could poverty be more tolerable, than where it was a matter of the highest piety to practice 
charity towards one's neighbour, that is, towards one's fellow-citizen, so that God their king would continue to look with favour upon them. ${ }^{59}$ The restitution of land in the Jubilee (forty-ninth) year, a divine requirement set out in Leviticus, was Cunaeus' "agrarian law". ${ }^{60}$ Spinoza stresses that land was distributed equally and to the perpetual ownership of the people. Those forced to sell their land had it restored to them (or their descendants) in the Jubilee year. To sell one's land was to enter into a debt which carried a guarantee of future cancellation so it could not devolve onto the next generation. The "other customs of this kind" Spinoza mentions likely include the sabbatical law which required other debts to be released every seventh year. ${ }^{61}$ Unpaid debts could not be met with seizure of land or enslavement, but had to be periodically forgiven. The success of the Hebrew state was partially attributable to the fact that equal ownership of land and freedom from debt were effectively inalienable rights there.

This point is not original to Spinoza, and by the time of the TheologicalPolitical Treatise its deployment in the Dutch republican context was already half a century old. Nelson explains the history of the republican uptake of the sabbatical and Jubilee debt-releases, arguing that while earlier writers appealed to these Biblical laws, Cunaeus most powerfully established their connection to the peace and security of the state. ${ }^{62}$ He posited the Jubilee restitution as the archetypal "agrarian law", indicating that permanent, equal land ownership and debt cancellation were God's will. For Cunaeus, the elimination of economic inequality is to the benefit of the state. The greed of the rich and the indebtedness of the poor put the poor at the mercy of the rich and leave them unable to access basic goods: "the avarice of a few should not invade the possessions distributed with so fair equality. It is not unusuall with rich men to thrust the poor [man] out of his inheritance, and deprive him of necessaries, 
whilst they enlarge their own estate superfluously". This situation prompts the poor to defection, sedition, and revolt. ${ }^{63}$ The "agrarian law", in creating greater economic equality, promotes political stability. ${ }^{64}$

Spinoza reinforces Cunaeus' point by reiterating that obedience to civil and religious law was one and the same. For the Israelites, to practise "charity towards one's neighbour" through cancelling debts was to obey God's law, and was thus a matter both of justice and of piety. As Nelson points out, there is no distinction in Hebrew between "justice" and "charity": the Hebrew tzedakah "refers both to the fulfilment of what we would regard as conventional legal obligations and to the performance of what we would regard as charitable acts". ${ }^{65}$ Since God is the owner of all things, all his requirements of human beings with respect to his land, including those that look discretionary, have the character of legal obligations. ${ }^{66}$ Tzedakah encompasses the obligatory repayment of debts and the (no less obligatory) charitable cancellation of debts. By fulfilling tzedakah, the Israelites met the overarching requirement of the divine law: to love their neighbours. In this way, they performed both justice and charity, perpetually enacting equal treatment and respect. Although all were not equally wise, all were equally obliged by and beneficiaries of tzedakah, and thus all were treated as equals. Neither debt nor domination could enslave anyone to anyone else: "no one was subject to his equal, each being subject only to God". ${ }^{67}$

By contrast, inequality characterized the decline of the Hebrew state. The priestly Levites became a "non-labouring elite" resented by the others, who were obliged to pay them with donations and taxes. The tribes became less unified, leading to strife, the violation of the divine law, and eventually the institution of a monarchy ${ }^{68}$ This separated civil from divine law and disrupted the tribes' equal rights and the peoples' equal land ownership. Although Spinoza does not mention it, the 
Bible and Talmud suggest that the violation of the land laws, including the Jubilee restitution, was characteristic of this period. ${ }^{69}$ As regards equality, Spinoza's message seems clear: the Hebrew state was most stable and its people flourished best when its confederated tribes had equal right, and its people enjoyed economic equality. Under these conditions, and through a strict code of behaviour enforced through religious devotion, the state was able not only to free its members to become better people, but actually to make them better people too.

\section{Charity and economic equality}

Spinoza does not imply that the equalities established by the Hebrews will necessarily lead to flourishing. Those equalities were appropriate for the conditions the Hebrews found themselves in; different socio-political circumstances demand different strategies. Nevertheless, as I will show in this final section, Spinoza suggests that enforcing economically egalitarian principles is precisely how modern states should legislate for charity.

Unlike justice, which Spinoza defines in chapter 16 of the TheologicalPolitical Treatise, charity is not explicitly defined. It is clear that by charity Spinoza does not mean personal philanthropy. Care for the poor, along with other matters of the observance of piety, is to be decided upon and undertaken only on sovereign authority in the interest of the state. ${ }^{70}$ The exercise of charity is no more a matter of individual discretion than the exercise of justice, and someone who attempts to dispense charity as an individual, against the legislation of the state, acts seditiously. This rule is supported by principles of human nature in the Ethics. Philanthropy is often motivated by pity, a passion in which we imitate the sad feelings of others and 
thereby diminish our own power; it is also linked to ambition, our desire to be esteemed for doing what pleases others. ${ }^{71}$ Acting from such feelings is not virtuous or free, and it weakens the recipient by making their wellbeing dependent on the feelings of others. Generosity may be used to gain advantages of social harmony and friendship, but no private person has the wealth to help everyone in need, or the power to unite a community. Only the state has these powers, "so the care of the poor falls upon society as a whole, and concerns only the general advantage". ${ }^{72}$ Charity is not a matter of the fortunate volunteering to help the less fortunate, but a legal obligation on everyone to help everyone else (tzedakah).

It is a law of human nature that it is good for people to help one another. Nobody can survive very long without the help of other human beings, and we flourish best when we work together - preferably amongst rational people - for everyone's advantage. Mutual aid enables people to increase their conative power by "provid[ing] themselves much more easily with the things they require". ${ }^{73}$ One form that mutual aid takes is economic exchange. Each of us requires many more things for the preservation of our bodies and minds than we can procure alone, and "money has provided a convenient instrument for acquiring all these aids". ${ }^{74}$ Another such instrument is credit and debt. Economic transactions take place on the basis of "virtual credit" where money is scarce or unavailable: the butcher keeps track of what the shoemaker owes him on the assumption that he will discharge the debt in the future when he needs a pair of shoes. Such systems also operate where money is inappropriate: a friend invites you to dinner on the tacit understanding that you return the favour at some point. ${ }^{75}$ Through both monetized economic exchange and creditand-debt relations we help one another to fulfil our needs; both are ways that humans 
work together for mutual advantage and build the communities through which we increase our reason, virtue, and freedom.

As with all forms of community-building, these relations are fraught with danger due to inequalities of reason. Spinoza remarks on economic exchange in Ethics IVP70 and P71: "A free man who lives among the ignorant strives, as far as he can, to avoid their favors". ${ }^{76}$ The problem is that the (ignorant) creditor's estimation of the value of his favour may be unequal to the (rational) debtor's estimation. The rational person "strives to join other men to him in friendship, not to repay men with benefits which are equivalent in their eyes": rational people help one another because they recognize that it is a law of their nature to do so, and thank one another with friendship and mutual love. Less rational people are likelier to be motivated by money, or by the prospect of receiving a benefit they perceive to be of equal value; "thankfulness" for them always takes the form of "a business transaction or an entrapment" ${ }^{77}$ Since it is rational to help one another, the rational person receives benefits and services on the understanding that she will thank the creditor by exercising her friendship whenever he needs help. She acts honourably on virtual credit, and does not expect to repay her debt financially or immediately, or with added interest. The creditor, who lacks understanding of the inherent benefit of mutual aid, expects repayment in coin or in kind, and may hate the debtor if she does not discharge her debt in the way he expects.

For Spinoza, a virtual credit system of mutual aid, in which honourable people help and show gratitude to each other as needed, fits better with human nature than a system that monetizes every favour. But since we cannot deal exclusively with rational people, "it often happens that it is necessary to accept favors from [the ignorant], and hence to return thanks to them according to their temperament". ${ }^{78}$ The 
peaceful exchange of benefits is the primary way in which we seek our advantage and that of others in a community. To facilitate this, money must be used universally to set agreed values to goods. As the intermediary between need and fulfilment, money becomes the universal object of desire: "its image occupies the mind of the multitude more than anything else". ${ }^{79}$ It is through and around money that we build a community: to acquire money, people must integrate their needs and aims, working with and for others, and interacting as buyers and sellers. ${ }^{80}$ These relationships, mediated by the image of money and the desire for it, are highly susceptible to passions of ambition, envy, pride, and despondency. To foster peaceful and stable economic sociability, conditions must be set to minimize these passions.

Ambition, envy, pride, and despondency are passions through which we compare ourselves to others, aligning our desires with theirs, comparing our joys and sadnesses in fulfilling them, and consequently thinking more highly or lowly of ourselves (or of others) than is just. ${ }^{81}$ Since money is universally desired and its image is foremost in most people's minds, and since it is involved in many interpersonal interactions, that image will always be associated with these passions. Economic inequality causes us to compare our power for desire-fulfilment with that of others, and to feel either proud or despondent - in either case diminishing our power. ${ }^{82}$ Spinoza's formula for overcoming passions is to dissociate the feeling from the image we take to cause it, ${ }^{83}$ but money cannot be dissociated from desire without destroying its function. A more realistic strategy is to dissociate the passions from our tendency to imagine other people's successes and failures in seeking their advantage. For the irrational majority, it is best if the state creates conditions that discourage such comparisons of powers from ever occurring. 
The state can do that through a more equal distribution of money. A good that is held in common does not arouse envy; if everyone has equal ability to acquire what they need, and no prospect of their needs being either over-indulged or marginalized, the most damaging comparative affects will be avoided. Economic equality also reinforces the performance of equal respect: being able to fulfil their desires to the same extent as others, people think of themselves as equally powerful and their interests as having equal weight. Income, prices, interest rates, and taxes should therefore be organized to facilitate economic equality in the interests of the stability of the state. ${ }^{84}$ Legislation against debilitating debt and exploitative employment must be instituted so that no one is subject to those he perceives to be his equals. The state legislates for charity by introducing systems through which people can benefit each other, maximizing their capacity to become ethically free, and minimizing their tendency to fall prey to harmful passions.

A good democratic state for Spinoza is one that aims for peace, stability, and strength through increasing the power of its constitutive citizens - which is to say, their reason, virtue, and freedom. But given the imaginative and passionate thinking of the majority, and given their misconceptions of their own power and what is good for it, it is preferable if people do not focus too much on the level of power they, or others, have achieved. The state is faced with a difficult balancing act: it must simultaneously encourage each person to increase her conative power, and encourage her to think of her conative power as equal to everyone else's. This balance is achieved through a combination of political equality enforced by justice, which opens the space in which people are able to increase their power; and economic equality enforced by charity, which provides the material conditions in which people actually do increase their power. For Spinoza, the right combination of equalities allows 
political freedom to give way to ethical freedom, such that the good citizen can also

become a good person.

\footnotetext{
${ }^{1}$ A version of this paper was first presented at the conference The Radical Enlightenment: the Big Picture and its Details in Brussels in May 2013. I would like to thank Steffen Ducheyne and the organizing team at the Vrije Universiteit Brussel, and to acknowledge the many helpful comments I received from listeners there and at subsequent events. Thanks also to the anonymous reviewer who suggested several helpful refinements.

${ }^{2}$ See Moira Gatens and Genevieve Lloyd, Collective Imaginings: Spinoza, Past and Present (London: Routledge, 1999).

${ }^{3}$ Recent examples include Matthew J. Kisner, Spinoza on Human Freedom (Cambridge: Cambridge University Press, 2011); Steven Frankel, "Determined to be free: the meaning of freedom in Spinoza's Theologico-Political Treatise", The Review of Politics 73 (2011), 55-76; Susan James, "Narrative as the means to freedom: Spinoza on the uses of the imagination", in Spinoza's Theological-Political Treatise: A Critical Guide, ed. Yitzhak Y. Melamed and Michael A. Rosenthal (Cambridge: Cambridge University Press, 2010), 250-67; Justin Steinberg, "Spinoza on Civil Liberation", Journal of the History of Philosophy 47:1 (2009), 35-58; and Tom Sorrell, "Spinoza's unstable politics of freedom", in Interpreting Spinoza: Critical Essays, ed. Charlie Huenemann (Cambridge: Cambridge University Press, 2008), 147-65.

${ }^{4}$ Spinoza's opposition to economic inequality is noted, for example, by Steinberg, pp. 54-6, and Susan James, "Power and Difference: Spinoza's Conception of Freedom", Journal of Political Philosophy 4:3 (1996), 207-28, pp. 225-6. The view that Spinoza positively endorses a liberal concept of equality is expounded by Jonathan Israel most concisely in A Revolution of the Mind: Radical Enlightenment and the Intellectual Origins of Modern Democracy (Princeton: Princeton University Press, 2010) (see also his Radical Enlightenment [Oxford: Oxford University Press, 2001]). Hasana Sharp makes the case for Spinoza's egalitarianism from the perspective of posthumanism in Spinoza and the Politics of Renaturalization (Chicago: Chicago University Press, 2011). Three studies that draw out the ambiguities of Spinoza's use of equality are Raia Prokhovnik, "Men are not born fit for citizenship, but must be made so': Spinoza and citizenship", Citizenship Studies 13:4 (2009), 413-29; Theo Verbeek, "Spinoza on Natural Rights", Intellectual History Review 17:3 (2007), 257-75; and Etienne Balibar, Spinoza and Politics, trans. Peter Snowdon (London: Verso, 1998). On gender equality and inequality in Spinoza's texts, see note 36 below.

${ }^{5}$ Benedict de Spinoza, Theological-Political Treatise, ed. Jonathan Israel, trans. Michael Silverthorne and Jonathan Israel (Cambridge: Cambridge University Press, 2007), 16:11 and 5:8. References (to TTP) are to Spinoza's chapter numbers and Akkerman's paragraph numbers used by Silverthorne and Israel.

${ }^{6}$ TTP $16: 15,17: 25$.

${ }^{7}$ TTP $15: 10$.

${ }^{8}$ Benedict de Spinoza, Ethics, in A Spinoza Reader: The Ethics and Other Works, ed. and trans. Edwin Curley (Princeton: Princeton University Press, 1994), IIP38C, IIP39C, IIP40. References are to E, and follow Curley's system of abbreviation: part number in roman numerals followed by proposition (P), corollary (C), scholium (S), or definition (D) number, or appendix (App.) section.

${ }^{9}$ E IVD8; cf. IVP20, P23.

${ }^{10}$ E ID7.

${ }^{11}$ E IVP4.

${ }^{12}$ Spinoza thinks that as reasoners we agree in nature, and thus we aim for greater sameness in our thinking and acting (see, e.g., E IVP35). The concepts of agreement and sameness, while related to equality, are, I think, sufficiently distinct that I am justified in not addressing them here. On the tensions arising from the state's need to make people more alike, see James, "Power and Difference", and Gatens and Lloyd, Collective Imaginings, ch. 5.
} 


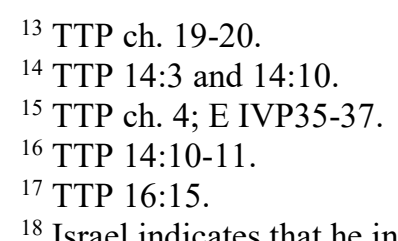

${ }^{18}$ Israel indicates that he interprets Spinoza in this way in an editorial footnote to TTP 16:15: "Equality is the essential principle of justice, for Spinoza, but also of his (secularized) moral philosophy and of what he regards as the best kind of state, namely democracy" (p. 203). This is added as if it were an uncontroversial editorial clarification.

${ }^{19}$ For a full development of this argument, see Beth Lord, "Spinoza, Equality, and Hierarchy", History of Philosophy Quarterly 31:1 (2014), 59-77. See also Verbeek, pp. 267-8, and Prokhovnik, 422-4.

${ }_{20}$ TTP 16:11.

${ }^{21}$ E IVP37S2; TTP 16:2. Note that Spinoza does not state that individuals have equal right, as Hobbes does (De Cive, ed. Howard Warrender [Oxford: Clarendon Press, 1983], I.3).

${ }^{22}$ TTP 16:3.

${ }^{23}$ On Spinoza's understanding of right as power, see Prokhovnik, Verbeek, and Balibar pp. 59-63.

${ }^{24}$ E IP34, IIIP6.

25 TTP 16:2.

${ }^{26}$ TTP 16:3.

${ }^{27}$ E IVP32-4.

${ }^{28}$ TTP 16:4.

${ }^{29}$ E IVP37S2.

${ }^{30} \mathrm{E}$ IVD8.

${ }^{31}$ TTP 20:6.

${ }^{32}$ E IVP35C1.

${ }^{33}$ TTP 16:11.

${ }^{34}$ Antonio Negri expresses this as the distinction between potestas as authoritative power, and potentia as conative power; see The Savage Anomaly, trans. Michael Hardt (Minneapolis: University of Minnesota Press, 1991).

35 TTP 16:15.

${ }^{36}$ For these purposes I understand legal equality to mean equality under the law, and political equality to mean equality in (directly or indirectly) making the law; see Stuart White, Equality (Cambridge: Polity, 2007), pp. 4-5. In a famous passage of his later Political Treatise, Spinoza states that over half the population of a democracy is not entitled to political equality: women, children, servants, and foreigners, who are not "in control of their own right" (Baruch Spinoza, Political Treatise, in Complete Works, ed. Michael L. Morgan, trans. Samuel Shirley [Indianapolis: Hackett, 2002], 11:3). In the Theological-Political Treatise Spinoza does not give any reason to think that individuals in these groups could not be good citizens in the sense of obedience to the law. This raises many interesting problems. For discussion see Genevieve Lloyd, Part of Nature: Self-Knowledge in Spinoza's Ethics (Ithaca: Cornell University Press, 1994), ch. 5; Moira Gatens, Imaginary Bodies (London: Routledge, 1996), and Beth Lord, "'Disempowered by nature': Spinoza on the political capabilities of women", British Journal for the History of Philosophy 19:6 (2011), pp. 1085-1106.

37 This is Frankel's argument; see especially pp. 66-7. On issues of recognition, see Gatens and Lloyd, and Sharp.

${ }^{38}$ TTP 5:8, cf. 17:4; see Frankel, p. 67.

39 TTP 5:9

40 TTP 5:9-10, 17:6.

${ }^{41}$ See Eric Nelson, The Hebrew Republic: Jewish Sources and the Transformation of European Political Thought (Cambridge, MA: Harvard University Press, 2010); Lea Campos Boralevi, "Classical Foundational Myths of European Republicanism: the Jewish Commonwealth", in Republicanism: A Shared European Heritage, vol. 1, ed. Martin van Gelderen and Quentin Skinner (Cambridge: Cambridge University Press, 2002), pp. 247-61; and Susan James, Spinoza on Philosophy, Religion and Politics: the Theologico-Political Treatise (Oxford: Oxford University Press, 2012), pp. 265-6.

${ }^{42}$ Nelson, The Hebrew Republic, p. 16

${ }^{43}$ James, Spinoza on Philosophy, Religion, and Politics, p. 265, cf. Boralevi, p. 250. Both draw this point from Simon Schama, The Embarrassment of Riches: An Interpretation of Dutch Culture in the Golden Age (London: Collins, 1987).

44 James, Spinoza on Philosophy, Religion, and Politics, pp. 266-9.

45 TTP 18:1. 
${ }^{46}$ Nelson, The Hebrew Republic, p. 59.

${ }^{47}$ Ibid., pp. 3-4, 59.

${ }^{48}$ TTP $17: 7$

${ }^{49}$ TTP 17:8, cf. 19:6; see James, Spinoza on Philosophy, Religion, and Politics, p. 270.

${ }^{50}$ TTP 17:9.

${ }^{51}$ See TTP 1:1-20.

${ }^{52}$ TTP 17:9

${ }^{53}$ TTP 17:10.

${ }^{54}$ See TTP 5:10.

${ }_{55}^{55}$ TTP 5:11; see James, Spinoza on Philosophy, Religion, and Politics, pp. 274-5.

${ }^{56}$ TTP 16:10.

57 "This much resembles the situation of the States General of the United Netherlands" says Spinoza, echoing Cunaeus (TTP 17:14).

${ }^{58}$ TTP 17:11, 17:12, 17:25.

${ }^{59}$ TTP 17:25.

${ }^{60}$ Leviticus 25:8-13. For discussion of the Biblical and rabbinical sources, see Nelson, The Hebrew Republic, ch. 2.

${ }^{61}$ Deuteronomy 15:1-2; Nelson, The Hebrew Republic, p. 67.

${ }^{62}$ Nelson, The Hebrew Republic, pp. 64-78. Radical protestant thinkers had used the sabbatical and Jubilee laws to argue against punitive interest rates and persistent debt, contributing in some cases to peasant revolts; see Benjamin Nelson, The Idea of Usury: From Tribal Brotherhood to Universal Otherhood, $2^{\text {nd }}$ ed. (Chicago: University of Chicago Press, 1969), ch. 2.

${ }^{63}$ Cunaeus, De Republica Hebraeorum, quoted in Nelson, The Hebrew Republic, p. 77.

${ }^{64}$ Recently anthropologist David Graeber has shown the socio-economic and political significance of such debt-cancelling arrangements in ancient societies. People in extreme debt typically became debtslaves, dispossessed of their belongings, their freedom, and frequently their family members, creating a subset of the population unable ever to pay their debts or to engage in normal socio-economic relations. As the number of debt-slaves increased such a society would become untenable, prompting rulers to "charitably" cancel all debts and restore equality. See David Graeber, Debt: The First 5,000 Years (New York: Melville House, 2011).

${ }^{65}$ Nelson, The Hebrew Republic, 65. Steven Nadler explains that tzedakah formed part of the structure of Amsterdam Jewish life in in Spinoza's time, in the form of taxes and compulsory donations:

Spinoza: A Life (Cambridge: Cambridge University Press, 1999), ch. 6. I am grateful to Anya Topolski for drawing my attention to the significance of this term for Spinoza and its economic connotations in her conference paper "Tzedakah: the True Religion of Spinoza's Tractatus?".

${ }^{66}$ Nelson, The Hebrew Republic, pp. 65-6.

${ }^{67}$ TTP 17:25.

${ }^{68}$ TTP 17:26, 17:29.

${ }^{69}$ Nelson, The Hebrew Republic, pp. 68-9.

${ }^{70}$ TTP 19:15.

${ }^{71}$ E IIIP27S, P27C3S, P29. Spinoza admits that helping others from pity is better than not helping them at all; see E IVP50S and his remarks on "almsgiving" in his correspondence with Blyenbergh (Letter

23 in Spinoza, Complete Works, pp. 833-4).

${ }^{72}$ E IVApp.xvii

${ }^{73}$ E IVP35S.

${ }^{74}$ E IVApp.xxviii. See also TTP 5:7, where Spinoza states that the organization of an economy rests on the need for mutual aid (this is clearer in Shirley's translation in Spinoza, Complete Works, p. 438).

${ }^{75}$ For discussion of the centrality of "virtual credit" to historical economies, see Graeber.

${ }^{76}$ E IVP70. "Favors" here translates beneficia, meaning benefits, services, or kindnesses. Note that at IVP51 and IIIDef.Aff.xix Curley also uses "favor" to translate favor, meaning appreciation for benefits: "a love toward him who has benefited another" (E IVP51).

${ }^{77}$ E IVP70-71, IVApp.xxviii.

${ }^{78}$ E IVP70.

${ }^{79}$ E IVApp.xxviii.

${ }^{80}$ For illuminating discussion of these themes, see Frédéric Lordon, Willing Slaves of Capital: Spinoza and Marx on Desire, trans. Gabriel Ash (London: Verso, 2014).

${ }^{81}$ E IIIP26S, P29S, P32S. 
${ }^{82}$ Richard Wilkinson and Kate Pickett make the same point, based on evidence from the social sciences, in The Spirit Level: Why More Equal Societies Almost Always Do Better (London: Allen Lane, 2009).

${ }^{83}$ E VP2-4.

${ }^{84}$ Passages in Spinoza's Political Treatise suggest practical means of achieving this in different kinds of political regime, e.g. 6:12, 7:8, 8:31, 9:8, 10:8. To understand these passages in historical context, see Prokhovnik. For an argument that the Political Treatise derives equality from monarchy, see Balibar, ch. 3. 